\title{
Statistical Analysis of Electronic BANKING SERVICES IN THE EU
}

\author{
STRUGAR, I.; KOKOLEK, N. \& JAKOVIC, B.
}

Abstract: This paper deals with various questions related to functionality and providing banking services in the European union on the Internet. Due to the fact that we live in the information technologies era, the Internet become a new space for doing economic and business activities in all areas, and especially important in banking. Accepting the busy tempo of life, in the past several years electronic banking has become necessity and a must for most users of banking services. On a sample of 300 web sites of the banks operating in European union (EU) we conduct the research on the functionality of e-banking services offered through banks web sites with the key objective to reveal to what extent the information technologies are used in their business operations. Characteristics of EU banks websites will be examined and compared to the basic groups of business activities on the web. Also some recommendations for the successful bank web sites will be provided.

Key words: electronic banking, electronic business, European union Banks, Internet, ANOVA
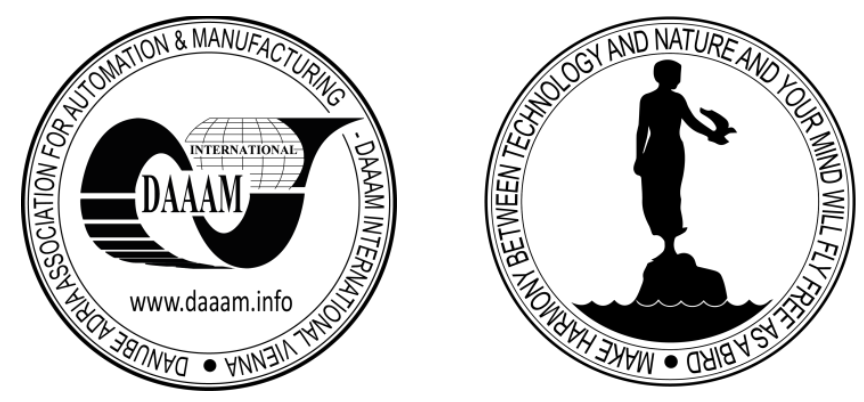

Authors' data: Univ.Prof. Ph.d. Strugar, I[van]; MA in Economics. Kokolek, $\mathrm{N}$ [atalija]; Assistant prof. Ph.d. Jakovic, B[ozidar]; University of Zagreb - Croatia, Faculty of Economics and Business, Square J.F.Kennedy 6, 10000, Zagreb, Croatia, istrugar@efzg.hr, nkokolek@gmail.com,bjakovic@efzg.hr

This Publication has to be referred as: Strugar, I[van]; Kokolek, N[atalija] \& Jakovic, B[ozidar] (2015). Statistical Analysis of Electronic Banking Services in the EU, Chapter 24 in DAAAM International Scientific Book 2015, pp.283-298, B. Katalinic (Ed.), Published by DAAAM International, ISBN 978-3-902734-05-1, ISSN 1726-9687, Vienna, Austria

DOI: $10.2507 /$ daaam.scibook.2015.24 
Strugar, I.; Kokolek, N. \& Jakovic, B.: Statistical Analysis of Electronic Banking S...

\section{Introduction}

Information technology and its pervasive use nowadays is one of the most frequently mentioned issue in the business world. Internet, major worldwide communication network, affirms the electronic market and the appearance of many new services which have an impact on business and society. The development of Internet technology, which is present everywhere in the world, has led to the possibility that the business is done electronically. We can conclude that we live in the era of "Electronic Business" or "eBusiness".

Electronic business is a modern form of business organization which involves intensive application of information and, particularly, Internet technology in all core business functions and processes (Panian, 2001). Today represents the most advanced form of business organization which tend to all companies targeted on better market positions and intensive development of business activities.

Internet, as one of the most important tools of promotion, and especially a website should be a 'mirror' of the company, mainly because it indicates how much effort has been done in promoting its own brand and how to evaluate Internet as a media.

Due to the successful realization of the idea of creating a virtual bank, electronic banking is the fastest, most economical and most efficient way of doing banking business. Times change and today's digital world has strong impacts on a range of consumer behavior, including the way they deal with their own finances. Electronics and mobility are key factor for financial institutions to be in progress. There have been a lot of research about the influence of e-business and related technologies on banking services. In a literature review we will analyze the evolution of the research in ebanking area and stress key conclusions. After that we will construct our own research methodology on a sample of 300 websites of the banks operating in EU around the functionality of e-banking services offered via web sites and revealed the its major functionalities and features.

\section{Literature overview}

E-Banking can be defined as banking products and services offered by the bank through Internet access that has obtained a license from the banking institution (Medyawati \& Mabruri, 2012). Over the last ten years the Internet has changed the rules for practically all industries, including the banking sector. Internet based applications have become an important vehicle for product marketing and distribution for many businesses. Internet banking, as a financial innovation and means of intermediation, has grown considerably during the last decade (Stoica et.al., 2015). Acharya et.al., 2008. have discussed the impact of online banking intensity on the financial performance of community banks. This study utilizes two different statistical procedures in constructing online banking and profit efficiency indices. Model estimates show that community banks with a wider range of online banking services are more proficient than those with limited web presence. Bravo et.al., 2012. have made 
a study and an analysis of corporate identity in Spanish banking institutions, focusing on the communication of identity elements through corporate Websites. A total of 230 categories related to six dimensions of corporate identity were identified. We could say that this paper is a snapshot of the sector's situation, which is constantly changing due to the sector's dynamism.

Malhotra \& Singh, 2010. investigated the status of Internet banking in India and the extent of Internet banking services offered by Internet banks. The paper presents data, drawn from a survey of commercial banks' Websites, on the number of banks that offer Internet banking and on the products and services they offer. The results show that the private and foreign Internet banks have performed well in offering a wider range and more advanced services of Internet banking in comparison with public sector banks.

According to Akhisar et.al., 2015., the effects of the electronic banking products on performance data were analyzed by using dynamic panel data methods for 23 developed and developing countries banking data. The most important differences of the study from other studies in the literature are both method and considered a large number of countries data. The findings indicate that almost all the banking services under consideration affect the profitability.

On the other hand, Tunay et.al., 2015. investigated the interaction between Internet banking and bank performance by panel causality tests. Banking data of 30 European countries were analyzed by Demitrescu - Hurlin panel causality test for the period 2005-2013. The whole sample is taken as 3 samples which are included: Euro and non-Euro Area, Euro and non-Euro countries. Results show that a strong relationship through Internet banking to the bank performance in the Euro Area countries and for the rest of the Euro Area countries are also not determined causation significantly in both directions.

The number of Websites offering banking services has grown rapidly using the new channels for transaction and communication offered by the medium, so that today almost all banks offer online services and information. According to Munoz-Leiva et.al., 2010. the purpose of their paper is to contribute to the field of trust research with focus on optimising this perception via electronic transactions in the banking industry. The analysis of these influences is based on an experimental design applied to Internet banking users with the aim of treating the scenarios defined by combinations of stimuli. It discovers that the mere presence of seals is not in itself important for the explanation of beliefs about trustworthiness and dependability of a website with electronic banking services.

Yang et.al., 2014. decomposed Website quality and profitability in e-commerce firms using two-stage DEA model. The samples in this study were mainly from ecommerce companies in the stock market of Shangai, Shenzhen, Hong Kong, National Association of Securities Deal Automated Quotations and Taiwan. Authors said that virtual operation in e-commerce firms needs to focus on e-business application match with organization structure and Internet strategy so that it can take advantage of cost savings to increase overall operation efficiency. Their findings provide interesting 
Strugar, I.; Kokolek, N. \& Jakovic, B.: Statistical Analysis of Electronic Banking S...

insights how to improve operation efficiency according to Website quality and profitability.

DeYoung et.al., 2007. have discussed about the impact of the Internet on bank performance. It is known that the most likely way that Internet banking can affect community banking is by influencing the nature of the relationships between banks and their customers. The purpose of their paper is how the Internet banking channel's impact on the financial performance, production process and product mix. Their study was focused on community bank performance during a two-year window from 1999 through 2001 according to their selection criteria. Authors found out that Internet adoption improved community bank profitability and increased use of brokered deposits and higher average wage rates for bank employees.

Casalo et.al., 2008. measured the influance of satisfaction and Website usability in developing customer loyality and positive word-of-mouth in the e-banking services. This research showed that satisfaction with previous interactions with the bank website had a positive effect on both customer loyalty and positive WOM.

Al-Khalifa, 2014. has emphasized the importance of mobile Websites for univesities. It is known that universities' Websites are portals that provide services and information to their visitors. They usually provide services such as news, events, campus maps, directories etc. The significance of his study resides in raising awareness of the importance of having effective university mobile websites. The framework consists of four categories: interface, navigation, content and services offered and technical aspects. They are divided into 13 sub-categories wit a total of 70 evaluation criteria compiled from previously validated frameworks. The main findings of the study show that universities are performing well in terms of content and services they provide, however further improvements need to be considered to incorporate more transactional services that facilitate accomplishing tasks more easily and quickly.

The concept of corporate social responsibility (CSR) has witnessed a resurgence in the management literature in recent years. Fatma \& Rahman, 2014. have made a study where they explore how banks communicate and form their corporate identity through CSR activities. The information has been taken from company Websites and annual reports and the results are limited to only Indian banks. The findings show that in India most of the banks are using CSR practices in their operations and communicating all this information with the help of their websites. According to Hinson et.al., 2010. which study included all 25 banks in Ghana, have found out that one of the banks that had won the most CSR awards at the Ghana banking awards had the poorest CSR communication content on its corporate website. It was also noted that banks that had never won a CSR award previously seemed to have a better organised structure in respect of their CSR activities on their websites.

\section{Research methodology}

As the basic for conducting this research, we use a sample of 300 banks operating in EU (in fact, their Web sites) from the list of banks in the EU published by Banks 
around the world, (2014). We also include all 30 banks operating in the Republic of Croatia, as a newcomer to EU, from the list of banks in the Republic of Croatia, published on the Website of the Croatian banking association, (2014). We collected data in the period from 01 August (the beginning of the research) to 01 September 2014 and used descriptive statistics methods with inductive conclusions.

A new model for analyzing Websites of European union Banks was presented by authors (Figure 1). All Websites of European union Banks should be view through five main forms: (1) Communication with customers on Websites of European union Banks, (2) Marketing elements on Websites, (3) Languages on Websites, (4) Bank services and (5) Usage of Web 2.0 technologies on group-buying portals. The central part of the research analyses the Websites of European Union Banks with particular regard to that model.

Similar model used Salavati and Hashim but they investigated the Website adoption and performance of Iranian hotels. The population of their study included 75 Iranian hotel Websites which were functional. The results showed the percentage of Websites in terms of their star ratings and the percentage of the hotel Websites that include each of 48 features that were classified under the six dimensions of hotel information, product information, non-product information, payment, customer relationship management and reservation. The results indicate that the page ranking and the hotel star rating are significantly related to Website performance.

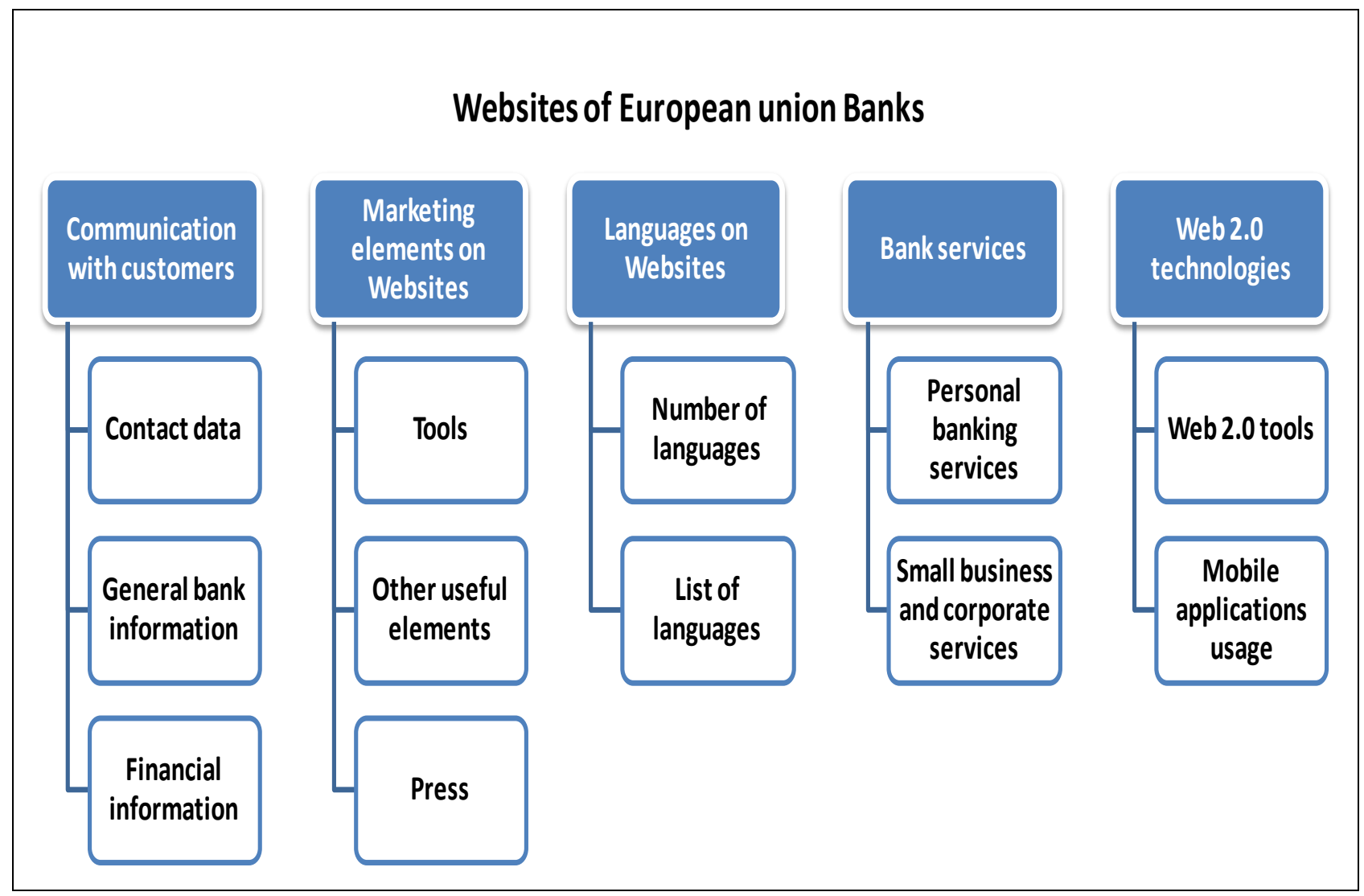

Fig. 1. Websites of European union Banks - research model 
In the planned and conducted research were analyzed the Websites of 30 banks in Croatia and 10 Websites of banks in each country of the 27 other members, or a total of 300 bank Websites of the Member States of the EU. The attributes in this study are: available business information which includes share capital, total assets, number of branches, employees, clients and financial reports, than forms of communication with clients which includes contact data, general bank information, press and other elements on the Website like useful links, news, suggestions, complaints, compliments and sitemap. Also, we depicted the evidences on the forms of Web 2.0 and mobile technologies usage, use of banking services for clients, including personal banking services and small and corporate business services. Due to the set methodology, which consists of attributes and 300 Websites of banks, research will show the availability and functionality of the EU banks on the Internet.

\section{Research results}

The information and communication technologies (ICT) sector is inextricably tied to today's economy and social life. ICT deeply penetrates in all walks of human life (Daneshgadeh \& Yildirim, 2014). The banking industry, highly affected by technology evolution, has transformed the way banks deliver their services, using technologies such phone banking, Internet banking and mobile banking (Al-Qeisi \& Hegazy, 2015).

Available and relevant information is important and useful element on the banks Websites. It includes some financial information such as share capital, total assets, number of branches, employees, clients and available financial reports.

\begin{tabular}{|c|c|c|}
\hline Available business information & $\begin{array}{c}\text { Share of European union } \\
\text { Banks which have the } \\
\text { stated element on their } \\
\text { website }\end{array}$ & $\begin{array}{c}\text { Share of } \\
\text { Croatian banks } \\
\text { which have the } \\
\text { stated element on } \\
\text { their website }\end{array}$ \\
\hline Share capital & $99,00 \%$ & $100,00 \%$ \\
\hline Total assets & $99,00 \%$ & $100,00 \%$ \\
\hline Number of branches & $87,33 \%$ & $73,33 \%$ \\
\hline Number of employees & $40,00 \%$ & $46,67 \%$ \\
\hline Number of clients & $37,00 \%$ & $30,00 \%$ \\
\hline Financial reports & $98,00 \%$ & $90,00 \%$ \\
\hline
\end{tabular}

Tab. 1. Available financial information on Websites of European Union banks in 2014

Table 1 represents available financial information found on Websites of EU banks. Share capital and total assets can be find on $99,00 \%$ of Websites in European 
union, and in Croatia all bank Websites have clearly stated this two items. Financial reports are available on $98 \%$ of Websites. Due to the success and popularity of banks depends on the number of clients and what is more branches available in the country, the grater probability is that a person will choose that bank, such data are essential. Number of branches can be find on $87,33 \%$, employees on $40,00 \%$ and number of clients on $37 \%$ of bank Websites.

The financial industry plays a key role in the production of information. There is a direct connection between financial and economic evolution. Financial sector has encouraged and promoted technological innovation and by these it has promoted economic development due to the mobilizing savings, evaluating projects, managing risk, monitoring managers and facilitating transactions (Kirakosyan \& Dănăiaţă, 2014).

The communication channels with clients includes contact data, general bank information, tools, some other elements like useful links, news, suggestion, sitemap, and finally press.

\begin{tabular}{|c|c|c|}
\hline $\begin{array}{c}\text { Forms of communication } \\
\text { with clients }\end{array}$ & $\begin{array}{c}\text { Share of European union } \\
\text { Banks which have the stated } \\
\text { element on their website }\end{array}$ & $\begin{array}{c}\text { Share of Croatian } \\
\text { banks which have } \\
\text { the stated element } \\
\text { on their website }\end{array}$ \\
\hline Contact data & $99,67 \%$ & $100,00 \%$ \\
\hline Telephone & $99,67 \%$ & $100,00 \%$ \\
\hline Telefax & $100,00 \%$ & $100,00 \%$ \\
\hline E-mail & $99,33 \%$ & $100,00 \%$ \\
\hline Adrress & & \\
\hline
\end{tabular}

Tab. 2. Communication channels with clients on Websites of European union banks in 2014

All Croatian bank Websites have clearly stated their telephone, telefax, address and e-mail which is also clearly stated on all Websites of European union Banks. A total of $99,67 \%$ of European union Banks have stated elements like telephone and telefax, and $99,33 \%$ have stated address on their Website.

Websites play an important role in e-business because through them users and clients find basic information about the bank. Table 3 represents available general bank information on Websites of Croatian banks and all members of EU.

Websites have nowadays become an essential media for any company as a form of advertising and also for any person who knows the basics of working on a computer. To make it easier to find the branch in the city, available branch network locations, headquarters and working hours shown on the Website are very useful. More than 95\% of EU banks have these stated elements on their Website. To find out automated teller machine network locations and their availability and functionalities have 83,00\% EU 
Strugar, I.; Kokolek, N. \& Jakovic, B.: Statistical Analysis of Electronic Banking S... banks on their Websites. Results for Croatian banks are similar to other banks in the EU.

In a situation where are so many competitors offering the same or similar services, companies need to define diversity points to the development of recognizable elements of brand identity. One of them is the advertising slogan and the other one is company's logo. Company's logo is a graphic sign or unique symbol which clients recognize in most situations. All 300 EU banks have their own logo. The importance of the advertising slogan was noticed by $25,33 \%$ of European banks which is a weak result and banks should make an effort in marketing activities. A slightly better result is related to the Croatian banks where 43,33\% have used slogans as part of their brand and advertising campaigns. Elements like companies registration code, bank account number, SWIFT and IBAN have more than $98,33 \%$ of Websites.

\begin{tabular}{|c|c|c|}
\hline $\begin{array}{c}\text { Forms of communication } \\
\text { with clients }\end{array}$ & $\begin{array}{c}\text { Share of European union } \\
\text { Banks which have the } \\
\text { stated element on their } \\
\text { website }\end{array}$ & $\begin{array}{c}\text { Share of Croatian } \\
\text { banks which have the } \\
\text { stated element on } \\
\text { their website }\end{array}$ \\
\hline \multicolumn{2}{|c|}{ General bank information } \\
\hline Headquarters & $99,67 \%$ & $100,00 \%$ \\
\hline Branch network locations & $97,00 \%$ & $96,67 \%$ \\
\hline Working hours & $95,67 \%$ & $83,33 \%$ \\
\hline ATM network locations & $83,33 \%$ & $76,67 \%$ \\
\hline ATM availability & $83,00 \%$ & $76,67 \%$ \\
\hline ATM functionalities & $83,00 \%$ & $76,67 \%$ \\
\hline Companies registration code & $99,33 \%$ & $100,00 \%$ \\
\hline Bank account number & $99,33 \%$ & $100,00 \%$ \\
\hline SWIFT & $98,33 \%$ & $90,00 \%$ \\
\hline IBAN & $99,00 \%$ & $96,67 \%$ \\
\hline Banking advertising slogan & $25,33 \%$ & $43,33 \%$ \\
\hline Banking logo & $100,00 \%$ & $100,00 \%$ \\
\hline
\end{tabular}

Tab. 3. Available general bank information on Websites of European union banks in 2014

Table 4 represents available tools and useful links during visits to banks Websites. Tools like calculator and exchange rate list, useful links, news and to write suggestions, 
complaints and compliments have most of the European union Banks on their Websites. A sitemap is a list of pages on a Website, typically organized in hierarchical order. This help visitors and search engine bots to find pages on the Website. More than half of Croatian banks have the stated element on their Website.

Newsletter are offered by $19,00 \%$, including Croatian $20,00 \%$ of banks which is a big minus for the banks because they don't use effective direct promotion of their own services.

E-banking is today oriented to customers and banks use it as a communication channel with clients and creating added value. Social networks represent a trend in social communication and in a short time have gained huge popularity. Members of social networks are not just students and young people looking for entertainment, but they are also intellectuals and business people all around the world.

\begin{tabular}{|c|c|c|}
\hline $\begin{array}{c}\text { Forms of communication } \\
\text { with clients }\end{array}$ & $\begin{array}{c}\text { Share of European union } \\
\text { Banks which have the } \\
\text { stated element on their } \\
\text { website }\end{array}$ & $\begin{array}{c}\text { Share of Croatian } \\
\text { banks which have the } \\
\text { stated element on their } \\
\text { website }\end{array}$ \\
\hline \multicolumn{3}{|c|}{ Tools } \\
\hline Calculator & $94,33 \%$ & $83,33 \%$ \\
\hline Exchange rate list & $97,00 \%$ & $100,00 \%$ \\
\hline \multicolumn{3}{|c|}{ Other } \\
\hline Useful links & $97,00 \%$ & $80,00 \%$ \\
\hline News & $99,67 \%$ & $70,00 \%$ \\
\hline $\begin{array}{c}\text { Suggestions, complaints, } \\
\text { compliments }\end{array}$ & $96,00 \%$ & $53,33 \%$ \\
\hline Sitemap & $62,67 \%$ & $96,67 \%$ \\
\hline \multicolumn{2}{|c|}{ Press reports } & Press \\
\hline Newsletter & $99,33 \%$ & $20,00 \%$ \\
\hline Social responsibility & $19,00 \%$ & $46,67 \%$ \\
\hline
\end{tabular}

Tab. 4. Available tools and other useful elements on Websites of European union banks in 2014

Web 2.0 includes new forms of social computing which bridge over cultural differences and have impact at development of the new Internet services. This kind of systems engages a huge number of users and it keeps developing from day to day.

Usage of Web 2.0 and mobile technologies on Websites of European union Banks includes: Facebook, Twitter, Google +, Linkedin profile, RSS, Flickr, Youtube, Chat and Blog. They also contain special mobile applications for usage. Table 5 shows the data on the share of EU and Croatian banks which have the stated forms of usage of Web 2.0 and mobile technologies on their Website. 
Strugar, I.; Kokolek, N. \& Jakovic, B.: Statistical Analysis of Electronic Banking S...

Facebook is the most used social network. $44,00 \%$ of the European union Banks use Facebook profile for additional promotion. 33,33\% of the banks Websites use Twitter, an online social network service that enables its users to send and read textbased post, known as tweets. Comparing with the Croatian banks, they should be more active on social networking sites, because only $36,67 \%$ of banks are active on Facebook and none on Twitter. Linkedin, the business social network is used by $19,67 \%$ in the European union, while Google + use 14,33\% banks. An image and video hosting Website and service, Flickr, use only 3,33\%. Contact the bank through live chat offer 5,00\% of banks. Instagram is not used by European union Banks.

\begin{tabular}{|c|c|c|}
\hline $\begin{array}{c}\text { Forms of Web 2.0 and } \\
\text { mobile technologies } \\
\text { usage }\end{array}$ & $\begin{array}{c}\text { Share of European union Banks } \\
\text { which have the stated element on } \\
\text { their website }\end{array}$ & $\begin{array}{c}\text { Share of Croatian } \\
\text { banks which have } \\
\text { the stated element } \\
\text { on their website }\end{array}$ \\
\hline Facebook & Web 2.0 tools & $36,67 \%$ \\
\hline Twitter & $44,00 \%$ & $0,00 \%$ \\
\hline Google + & $33,33 \%$ & $3,33 \%$ \\
\hline Linkedin & $14,33 \%$ & $6,67 \%$ \\
\hline RSS & $19,67 \%$ & $6,67 \%$ \\
\hline Flickr & $12,33 \%$ & $3,33 \%$ \\
\hline Youtube & $3,33 \%$ & $16,67 \%$ \\
\hline Chat & $28,00 \%$ & $6,67 \%$ \\
\hline Blog & $5,00 \%$ & $6,67 \%$ \\
\hline Instagram & $4,00 \%$ & $0,00 \%$ \\
\hline Apple store & $0,00 \%$ & $50,00 \%$ \\
\hline Google play & Mobile applications & $46,67 \%$ \\
\hline Usage of Web & 59,67 & \\
\hline
\end{tabular}

Tab. 5. Usage of Web 2.0 and mobile technologies on Websites of European union banks in 2014

Another statistic is the usage of mobile applications. Mobile applications are software applications, usually designed to run on smart phones and tablet computers. They are available through application distribution platforms, which are typically operated by the owner of the mobile operating system, such as the Apple App Store or Google Play. Mobile banking application offers more than 58,33\% of banks which will increase in the future due to rapid development of mobile technology.

According to the table 6 it can be seen that 40,33\% of surveyed banks provides page content in two languages, while $35 \%$ provides an overview of Websites in just their official language which is unsatisfactory information. Page content in five languages provides only one bank, Rietumu Bank from Latvia. The most Website 
banks in Croatia have been translated in two languages, $60 \%$, which is satisfactory result.

\begin{tabular}{|c|c|c|}
\hline Forms provided by the website & $\begin{array}{c}\text { Share of European union } \\
\text { Banks which have the } \\
\text { stated element on their } \\
\text { website }\end{array}$ & $\begin{array}{c}\text { Share of } \\
\text { Croatian banks } \\
\text { which have the } \\
\text { stated element } \\
\text { on their website }\end{array}$ \\
\hline \multicolumn{2}{|c|}{ Content languages on Websites } \\
\hline One language & $35,00 \%$ & $30,00 \%$ \\
\hline Two languages & $40,33 \%$ & $60,00 \%$ \\
\hline Three languages & $12,00 \%$ & $6,67 \%$ \\
\hline Four languages & $2,33 \%$ & $3,34 \%$ \\
\hline
\end{tabular}

Tab. 6. Number of languages on Websites of European union banks in 2014

According to table 7, all banks in Croatia offer the services on their Web sites in the official language and it refers to $97,33 \%$ in the European union. 60,33\% of Websites are available in English.

\begin{tabular}{|c|c|c|}
\hline Forms provided by the website & $\begin{array}{c}\text { Share of European union } \\
\text { Banks which have the } \\
\text { stated element on their } \\
\text { website }\end{array}$ & $\begin{array}{c}\text { Share of } \\
\text { Croatian banks } \\
\text { which have the } \\
\text { stated element } \\
\text { on their website }\end{array}$ \\
\hline \multicolumn{2}{|c|}{ Language } \\
\hline Official language & $97,33 \%$ & $100,00 \%$ \\
\hline English & $60,33 \%$ & $66,67 \%$ \\
\hline German & $4,67 \%$ & $3,33 \%$ \\
\hline French & $2,00 \%$ & $0,00 \%$ \\
\hline Italian & $1,00 \%$ & $6,67 \%$ \\
\hline Other & $16,00 \%$ & $6,67 \%$ \\
\hline
\end{tabular}

Tab. 7. List of languages on Websites of European union banks in 2014

Banking business is based on innovation and improving relationships with customers and put a special focus on the youth segment of clients. Table 8 shows the data on share of European union Banks which have the stated form of personal banking services on their Website.

Banks offer their clients a wide range of savings and investment products. More than 50,33\% of banks offer opening account and savings for young people, while $47,33 \%$ offer students help in the financing education with a selection of student loans.

Due to the main focus of the users and customers, it is important that services are clearly identified and specified so that users can find all the information they are 
Strugar, I.; Kokolek, N. \& Jakovic, B.: Statistical Analysis of Electronic Banking S...

looking for. Opening the different types of accounts, contracting the savings, offering loans and several cards with deposit accounts, and access to online banking on Websites of European union Banks have clearly stated more than 97,33\% of banks. Insurance such as life insurance, accident insurance, housing loan insurance offer $52,00 \%$ of banks in the European union.

\begin{tabular}{|c|c|c|}
\hline $\begin{array}{c}\text { Forms of banking services for } \\
\text { clients }\end{array}$ & $\begin{array}{c}\text { Share of European union } \\
\text { Banks which have the } \\
\text { stated element on their } \\
\text { website }\end{array}$ & $\begin{array}{c}\text { Share of } \\
\text { Croatian banks } \\
\text { which have the } \\
\text { stated element } \\
\text { on their website }\end{array}$ \\
\hline Personal banking services (Youth and student banking) \\
\hline Accounts & $53,66 \%$ & $53,33 \%$ \\
\hline Savings & $50,33 \%$ & $53,33 \%$ \\
\hline Student loans & $47,33 \%$ & $33,33 \%$ \\
\hline Personal banking services & & $100,00 \%$ \\
\hline Accounts & $98,00 \%$ & $96,67 \%$ \\
\hline Savings & $97,33 \%$ & $20,00 \%$ \\
\hline Insurance & $52,00 \%$ & $96,67 \%$ \\
\hline Cards & $98,00 \%$ & $96,67 \%$ \\
\hline Credits & $97,00 \%$ & $100,00 \%$ \\
\hline Online banking & $97,67 \%$ & $50,00 \%$ \\
\hline Mobile banking & $59,33 \%$ & $56,67 \%$ \\
\hline SMS banking & $76,67 \%$ & $3,33 \%$ \\
\hline Queuing app & $1,00 \%$ & \\
\hline
\end{tabular}

Tab. 8. Available personal banking services on Websites of European union banks in 2014

SMS banking is a type of mobile banking, enabling clients to use banking services over mobile phones using SMS messaging. 76,67\% of banks offer these service, while mobile banking is offered by 59,33\%. Worth mentioning is Erste Queueing, mobile app which allows you to draw a virtual queuing number at the Erste Bank branch office of choice and informs you how many people are ahead of you in line, thus enabling you to avoid long waiting times at the branch office.

Table 9 shows the services offered by banks to small businesses and corporates. Today many companies seek a consistent approach to optimize the entire financial supply chain - from purchasing and sales to payment and collection. Payment services and savings offers $98,00 \%$ of European union Banks. Financial services, online banking and SmartOffice offers more than $97,33 \%$ of banks.

International Desk provides information and support to all corporate clients about Bank Group, particular banks and their products and services and intermediates contacts to account managers. This service is offered by $86,67 \%$ of banks. 
According to the model of research, in which we include communication with customers, marketing elements, the number of languages, banking services and Web 2.0 technologies following results were obtained. The reason for doing Anova is to see if there is any difference between groups on some variable (Bowerman et.al.,2014).

\begin{tabular}{|c|c|c|}
\hline $\begin{array}{c}\text { Forms of banking services for } \\
\text { clients }\end{array}$ & $\begin{array}{c}\text { Share of European union } \\
\text { Banks which have the } \\
\text { stated element on their } \\
\text { website }\end{array}$ & $\begin{array}{c}\text { Share of } \\
\text { Croatian banks } \\
\text { which have the } \\
\text { stated element } \\
\text { on their website }\end{array}$ \\
\hline \multicolumn{2}{|c|}{ Small business and corporate services } \\
\hline Accounts & $98,00 \%$ & $100,00 \%$ \\
\hline Savings & $98,00 \%$ & $96,67 \%$ \\
\hline Financing & $99,33 \%$ & $100,00 \%$ \\
\hline International desk & $86,67 \%$ & $43,33 \%$ \\
\hline Online banking & $97,33 \%$ & $100,00 \%$ \\
\hline SMS banking & $77,66 \%$ & $53,33 \%$ \\
\hline SmartOffice & $97,33 \%$ & $100,00 \%$ \\
\hline Queuing app & $1,00 \%$ & $3,33 \%$ \\
\hline
\end{tabular}

Tab. 9. Available small business and corporate services on Websites of European union banks in 2014

\begin{tabular}{|c|c|c|c|c|c|}
\hline \multicolumn{6}{|c|}{ Anova: Single Factor } \\
\hline \multicolumn{6}{|l|}{ SUMMARY } \\
\hline Groups & Count & Average & Variance & & \\
\hline Success $>75 \%$ & 67 & $78,66 \%$ & 0,001199 & & \\
\hline Success $50-75 \%$ & 212 & $65,98 \%$ & 0,003963 & & \\
\hline Success $<50 \%$ & 21 & $41,90 \%$ & 0,010706 & & \\
\hline \multicolumn{6}{|l|}{ ANOVA } \\
\hline Source of Variation & $S S$ & $M S$ & $F$ & $P$-value & $F$ crit \\
\hline Between Groups & 2,256008 & 1,128004 & 296,616 & 0,0000 & 3,026153 \\
\hline Within Groups & 1,129464 & 0,003803 & & & \\
\hline Total & 3,385472 & & & & \\
\hline
\end{tabular}

Tab. 10. Analysis of variance (ANOVA) for an average number of elements per content group 
Websites of banks in the EU on average have 4 elements related to communication with customers, 11 elements that are related to the general information and 4 elements to business information. Bank services have 8 elements in connection with general bank information and 4 elements with financial information. Considering to the fact that the Internet is extremely important in many fields and it affects nearly every aspect of modern life, on the Websites of banks there are on average 8 elements concerning Web 2.0 tools and mobile application usage. For easy managing Websites, banks on average offer 2 languages with relatively low standard deviation.

According to all the indicators in our analysis, banks can achieve a maximum of 85 points, which means they use the maximum number of elements in each of the five main categories of research model. After analyzing indicators, banks were classified into three groups according to sucess. The first group is the group of successful banks with more than $75 \%$ of the total points, the second group includes banks achieving to $50 \%-75 \%$ of points in the third, and the least group, the least successful, includes bank achieving to less than $50 \%$ of points.

After research and analysis of all attributes, Table 10 contains data on the number of banks that are classified into one of three groups related to performance. In the first group, there are 67 banks in the EU, with an average level of success of $78.67 \%$. The largest number of banks, 212 of them are in the second group with an average level of performance of $65.98 \%$, and in the last group, with the level of success less than $50 \%$, are 21 banks.

In order to investigate whether this difference is statistically significant, we carried out an analysis of variance which showed that the average number of elements differs in a statistically significantly way per content group with a level of significance of $1 \%$.

\section{Conclusion}

This paper presents the results based on the analysis of e-banking services available in the EU member states. The study includes $300 \mathrm{Website}$ banks in the EU, precisely 30 Croatian banks and 270 Website banks of other Member States. Websites have nowadays become an essential medium for any company as a form of advertising. The main reason for such an expansion of banking services on the Internet is the fact that users are more versed in the benefits of its use and the slow disappearance of fear of using new technologies. Taking advantage of the e-banking, it is not surprising that $97,56 \%$ of banks in the EU offers the services on the Internet. This result indicates that citizens, entrepreneurs and companies are realizing that online banking achieved significant savings in daily operations. Moreover, 59,34\% of surveyed banks offer services through smart phones, so, mobile banking has great potential and prospects for further development, especially since it is known that the number of mobile phone users is constantly growing. Banks in the EU, including Croatia, should contribute to the popularization of the use of Internet services by establishing direct line of 
communication with their clients, instead of traditional way of support by phone. But, despite the simple introduction of this communication channel, only $14,92 \%$ of banks in Croatia used Web 2.0 technologies which indicates they are not ready to exploit the faster communicating possibilities to the full.

According to the results of the research, it can be said that e-banking services in Croatia are of the similar functionality compared to the other banks in the EU. However, it requires a lot of investment and taking the best from technology so the services can be at the top level. Time and technology won't wait for anyone, so those banks which fail to catch up with the time and new technologies, can be quickly find in a difficult situation.

\section{Referrences}

Acharya, R. N. \& Kagan, A. \& Lingam, S. R. (2008). Online banking applications and community bank performance, International Journal of Bank Marketing, Vol. 26 (2010) Iss 6 pp. $418-439$

Al-Khalifa, H.S. (2014). A framework for evaluating university mobile websites, Online Information Review, Vol. 38 (2014) Iss 2 pp. 166 - 185

Alkhisar, I. \& Tunay, K. B. \& Tunay, N. (2015). The Effects of Innovations on Bank Performance: The Case of Electronic Banking Services, Procedia - Social and Behavioral Sciences, Vol. 195 (2015) pp. 369 - 375

Al-Quesi, K. \& Hegazy, A. (2015). Consumer online behaviour: A perspective on Internet banking usage in three Non-Western Countries, Procedia Economics and Finance, Vol. 23 (2015) pp. 386 - 390

Bowerman, B. L. \& O'Connell, R.T. \& Murphree, E.S. (2014). Business statistics in Practise, McGraw-Hill/Irwin

Bravo, R. \& Pina, J. M. \& Matute, J. (2012). Communicating Spanish banks' identities: the role of websites, Online Information Review, Vol. 36 (2012) Iss 5 pp. 675 - 697 Casaló, L. V. \& Flavián, C. \& Guinalíu, M. (2008). The role of satisfaction and website usability in developing customer loyalty and positive word-of-mouth in the e-banking services, International Journal of Bank Marketing, Vol. 26 (2008) Iss 6 pp. 399 - 417 Daneshgadeh, S. \& Yildirim, S. Ö. (2014). Empirical investigation of internet banking usage: The case of Turkey, Procedia Technology, Vol. 16 (2014) pp. 322 - 331

DeYoung, R. \& Lang, W.W. \& Nolle, D.L. (2007). How the Internet affects output and performance at community banks (Original Research Article), Journal of Banking \& Finance, Vol. 31 (2007) pp.1033-1060

Fatma, M. \& Rahman, Z. (2014). Building a corporate identity using corporate social responsibility: a website based study of Indian banks, Social Responsibility Journal, Vol. 10 (2014) Iss 4 pp. $591-601$

Hinson, R. \& Boateng, R. \& Madichie, N. (2010). Corporate social responsibility activity reportage on bank websites in Ghana, International Journal of Bank Marketing, Vol. 28 (2010) Iss 7 pp. $498-518$ 
Strugar, I.; Kokolek, N. \& Jakovic, B.: Statistical Analysis of Electronic Banking S...

Kirakosyan, K. \& Dănăiaţă, D. (2014). Communication management in electronic banking. Better communication for better relationship, Procedia - Social and Behavioral Sciences, Vol. 124 (2014) pp. 361 - 370

Malhotra, P. \& Singh, B. (2010). An analysis of Internet banking offerings and its determinants in India, Internet Research, Vol. 20 (2014) Iss 1 pp. 87 - 106

Medyawati, H. \& Mabruri, A. (2012). Website Quality: Case Study on Local Government Bank and State own Bank in Bekasi City, Procedia - Social and Behavioral Sciences, Vol. 65 (2012) pp. 1086 - 1091

Muñoz-Leiva, F. \& Luque-Martínez, T. \& Juan Sánchez-Fernández, J. (2010). How to improve trust toward electronic banking, Online Information Review, Vol. 34 (2010) Iss 6 pp. $907-934$

Panian, Z. (2001). The Wealth of Internet, Strijelac, Zagreb

Salavati, S. \& Hashim, N. H. (2015). Website adoption and performance by Iranian hotels (Original Research Article), Tourism Management, Vol. 46 (2015) pp.367 -374 Spremic, M. \& Kokolek, N. \& Jakovic, B. \& Simurina, J. (2015). Marketing and Commercial Activities Offered on Websites of European Union Banks, Available from: http://waset.org/Publications/marketing-and-commercial-activities-offered-onwebsites-of-european-union-banks/10001476 - International Scholary and Scientific Research \& Innovation (2015), Accesed:2015-09-25

Stoica, O. \& Mehdian, S. \& Sargu, A. (2015). The impact of internet banking on the performance of Romanian banks: DEA and PCA approach, Procedia - Social and Behavioral Sciences, Vol. 20 (2015) pp. $610-622$

Tunay, K. B. \& Tunay, N. \& Alkhisar, I. (2015). Interaction Between Internet Banking And Bank Performance: The Case of Europe, Procedia - Social and Behavioral Sciences, Vol. 95 (2015) pp. 363 - 368

Yang, Z.F. \& Shi, Y. \& Wang, B. \& Yan, H. (2014). Website Quality and Profitability Evaluation in Ecommerce Firms Using Two-stage DEA Model (Original Research Article), Procedia Computer Science, Vol. 30. pp.4-13 